\title{
Compassionate Embodied Virtual Experience Increases the Adherence to Meditation Practice
}

\author{
Jaime Navarrete 1, Marian Martínez-Sanchis ${ }^{1,2}$, Miguel Bellosta-Batalla ${ }^{1,3}$, Rosa Baños ${ }^{1,2,4}$, Ausiàs Cebolla ${ }^{1,4}$ and \\ Rocío Herrero $1,2,4$,*
}

Citation: Navarrete, J.; MartínezSanchis, M.; Bellosta-Batalla, M.; Baños, R.; Cebolla, A.; Herrero, R. Compassionate Embodied Virtual Experience Increases the Adherence to Practice Meditation. Appl. Sci. 2021, 11, 1276. https://doi.org/ 10.3390/app11031276

Received: 27 November 2020

Accepted: 25 January 2021

Published: 30 January 2021

Publisher's Note: MDPI stays neutral with regard to jurisdictional claims in published maps and institutional affiliations.

Copyright: () 2021 by the author. Licensee MDPI, Basel, Switzerland. This article is an open access article distributed under the terms and conditions of the Creative Commons Attribution (CC BY) license (http://creativecommons.org/licenses/by/4.0/).
1 Department of Personality, Evaluation and Psychological Treatments, University of Valencia, 46010 Valencia, Spain; nahijai@uv.es (J.N.); marian.1592@gmail.com (M.M.-S.); Miguel.Bellosta@uv.es (M.B.-B); Rosa.Banos@uv.es (R.B.); ausias.cebolla@uv.es (A.C.)

2 Polibienestar Institute, University of Valencia, 46022 Valencia, Spain

3 El arte de Escuchar, Psychotherapy and Mindfulness. C/Madre Teresa Jornet, 10, 46009 Valencia, Spain

4 CIBER of Physiopathology of Obesity and Nutrition (CIBEROBN), 28029 Madrid, Spain

* Correspondence: ro.herrero.09@gmail.com

\begin{abstract}
Virtual Reality (VR) could be useful to overcome imagery and somatosensory difficulties of compassion-based meditations given that it helps generate empathy by facilitating the possibility of putting oneself into the mind of others. Thus, the aim of this study was to evaluate the effectiveness of an embodied-VR system in generating a compassionate response and increasing the quality and adherence to meditation practice. Health professionals or healthcare students $(n=41)$ were randomly assigned to a regular audio guided meditation or to a meditation supported by an embodiedVR system, "The machine to be another". In both conditions, there was an initial in-person session and two weeks of meditation practice at home. An implicit measure was used to measure prosocial behavior, and self-report questionnaires were administered to assess compassion related constructs, quality of meditation, and frequency of meditation. Results revealed that participants from the embodied-VR condition meditated for double the amount of time at home than participants who only listened to the usual guided meditation. However, there were no significant differences in the overall quality of at-home meditation. In conclusion, this study confirms that embodied-VR systems are useful for increasing adherence to meditation practice.
\end{abstract}

Keywords: virtual reality; compassion; the machine to be another; adherence; meditation

\section{Introduction}

Virtual reality (VR) has been shown to be an interesting and promising tool to generate empathy, especially the component regarding viewing others' perspectives [1], showing that it can facilitate the possibility of putting oneself into the mind of others. It has been shown to be effective in changing attitudes, beliefs, and affect [2-4]. In fact, VR has been defined as the ultimate empathy machine [5]. Furthermore, the appearance of embodied-VR systems, which include all the theories about how we represent the body to generate a full body illusion or body swap [6], are opening new pathways to better understand the role of VR in empathy, making it possible to not only put one's mind but also to put oneself as a whole into the mind of others.

Moreover, in recent years there have been some interesting studies about the effects of VR on related concepts, such as compassion and self-compassion. Compassion meditations are Buddhism-derived practices aimed at developing affective positive states of kindness and a sincere sympathy for those stricken by misfortune, together with an earnest wish to ease this suffering [7]. Compassion has been a focus of great interest in recent years, leading to theoretical and efficacy studies which have shown that the training of 
this factor through compassion-based interventions (CBIs) has an impact on the improvement of mental health [8], positive attitudes toward others [9] and stress management [10]. In compassion-based meditations, the meditator purposefully strengthens his/her natural capacity for loving-kindness and compassion by intentionally generating compassionate thoughts, feelings, and motivations toward different objects, including him/herself [11]. This is a type of constructive meditation [12] in which mental imagery plays an essential role, given that one must create a clear compassionate image (oneself or others), sustain it, and manage it [13]. However, previous studies have shown how barriers and difficulties can arise during these types of practices [14], such as difficulties regarding mental imagery. These difficulties are understood as problems to generate, maintain, inspect and/or transform the mental image of the person to whom one generates compassion toward, and, in regard to somatosensory experiences, which is related to the warmth, comfort, and sympathy felt during compassion meditation. Furthermore, these difficulties can generate a lack of practice quality and thus be barriers for the adherence to the practice of meditation [14].

VR, specifically embodied-VR, can be a helpful tool to manage these difficulties [15] and could be a useful tool to increase the positive affect response and meditation quality practice. Few studies have been developed the use of embodied VR to generate a compassionate response toward oneself or others. For example, Falconer et al. [16] found how a VR experience was able to generate a self-compassionate response reducing self-criticism and increasing self-compassion and positive affect states.

In a previous study, our research group tested how an embodied-VR system, called the machine to be another (TMTBA), was able to generate a compassionate response toward the self and a greater self-care response [15,17]. In addition, those who had worse imaginative abilities were the ones that benefited the most, opening the door for their use in patients with imagination difficulties. One of the hypotheses we considered was that perhaps meditative experience supported by embodied VR could increase the quality of compassionate practice or greater adherences; however, we could not find differences between conditions.

Current research on maintaining positive health behaviors, such as meditation, shows that people fail to sustain them in the months after the initiation $[18,19]$. Although more research on adherence to health behaviors is needed, it has been recently shown that positive affect experienced in the initiation of prosocial behavior [20] and physical activity [21] predicts their maintenance. Cappellen et al. [22] theoretically supported these findings from the upward spiral theory of lifestyle change [23]. Further, they hypothesized that the more positive affect experienced during initial phases in the learning process of meditation, the more impact in long-term behavioral maintenance through nonconscious motives for meditation. Finally, they reported that positive emotions experienced by firsttime participants performing a loving-kindness meditation predicted a higher frequency and longer duration of home practice [22].

In this study, analogous to our prior work that used compassion toward self-approach [15], we sought to test the efficacy of a compassion-based meditation supported by an embodied-VR microintervention to increase the quality and adherence to the practice of compassion-based meditation in a population that is particularly used to showing compassion toward others-healthcare professionals. Thus, in contrast to our previous study, the meditation supported by the TMTBA was aimed at enhancing compassion toward others in a bigger and specific sample. For this purpose, participants took over the body of a patient suffering a panic disorder and then directed their compassionate responses toward him. Moreover, an ecological momentary assessment of both frequency and quality of meditation practice was carried out, and an implicit task of prosocial behavior was used to complement self-reported measures. 


\section{Materials and Methods}

\subsection{Participants}

The study was approved by the Ethics Committee of Research in Humans of the Ethics Commission in Experimental Research of University of Valencia (H1513592028862). The size of the sample was calculated with the G-Power program, taking 0.33 as a measure of effect size (probability of alpha $=0.05$ for the desired power of $95 \%$ ) from the results on the effect of TMTBA on adherence values obtained in a previous pilot study [15]. Thus, we estimated the need to include 32 participants in the sample. However, we increased the sample size to compensate for potential alterations in the significance of the results as a result of possible dropouts. Participants were randomly allocated to one of two conditions: guided compassion-based meditation or guided meditation supported by TMTBAVR. The screening was completed with 81 participants, but only 44 met the criteria (see Figure 1). The inclusion criteria were: (a) being older than 18 years; (b) being a healthcare professional or student in recent years; (c) having a good level of Spanish or Valencian. The exclusion criteria were: (a) having a current diagnosis of a psychological/neurologi$\mathrm{cal} /$ psychiatric disorder; (b) currently undergoing psychological treatment; (c) substance use or abuse; (d) being a regular practitioner of any meditation practice (more than 5-6 times per week; this criterion is based on mindfulness-based stress reduction [24] and mindfulness-based cognitive therapy [25] curriculum guides.

\section{Enrollment}

Assessed for eligibility $(n=81)$

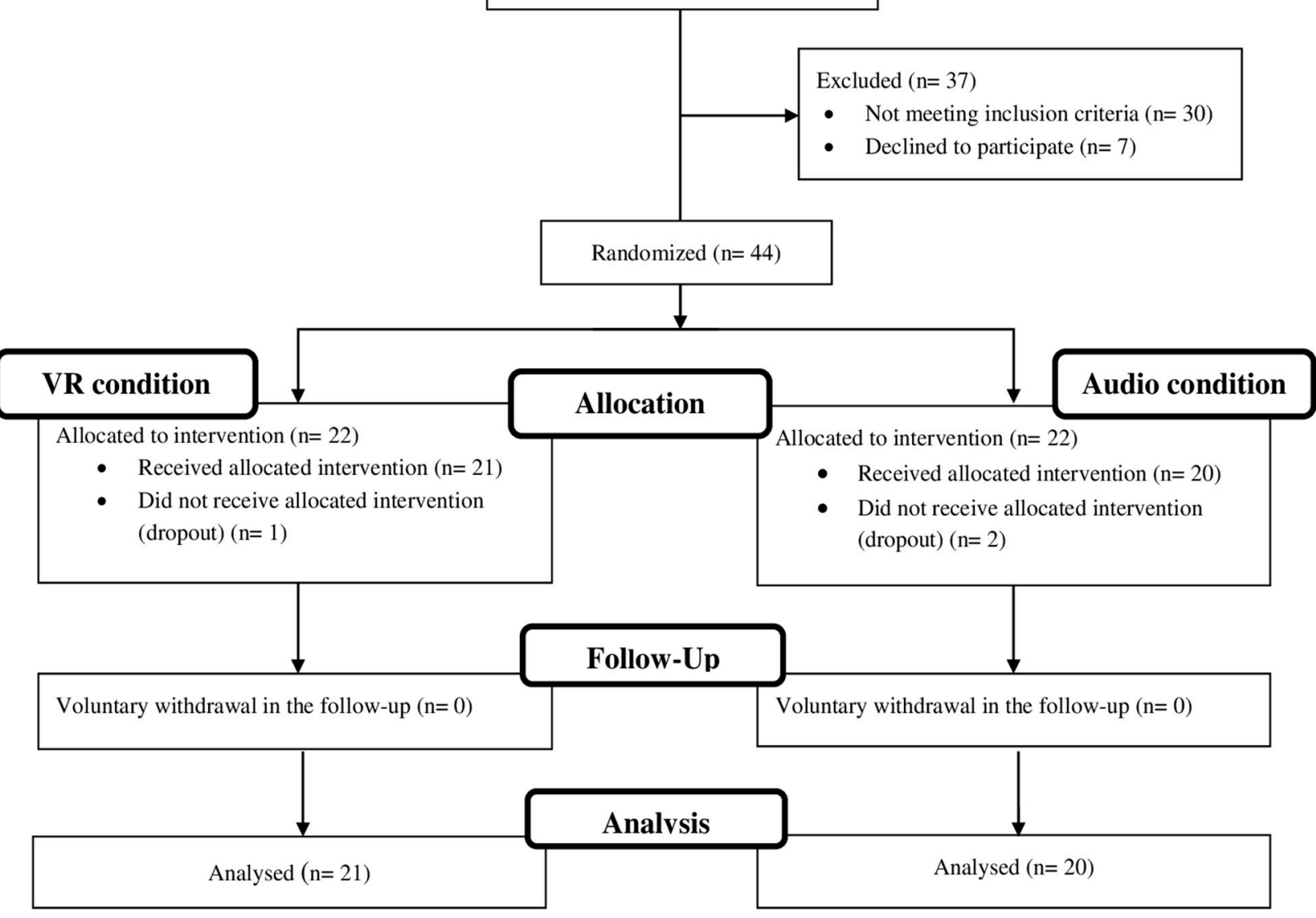

Figure 1. Participants' flow diagram. 


\subsection{Measures}

\subsubsection{Pre- and Postintervention Measures}

Sociodemographic data on age, gender, highest educational level attained, history of mental or chronic illness, use or abuse of drugs, current psychological treatments, and experience with meditation were collected as part of the screening process for the study with an ad-hoc questionnaire.

Affect was measured using the Positive and Negative Affect Schedule (PANAS; $[26,27])$. It includes 20 items that evaluate positive affect (10 items) and negative affect (10 items). Internal consistency was adequate for negative PANAS (Cronbach's $\alpha=0.88-0.90$ ) and positive PANAS (Cronbach's $\alpha=0.74-0.90$ ).

Compassionate or altruistic love for others was assessed using the Compassion Love Scale (CLS; [28]). It includes 21 items with a 7-point Likert scale ranging from 1 (strongly disagree) to 7 (strongly agree). A global factor can be calculated (Cronbach's $\alpha=0.90$ 0.92).

\subsubsection{Pre- and Post-in-Person Session Measures}

Mindfulness state was assessed before and after the in-person session using the State Mindfulness Scale (SMS; [29]). The scale is composed of 21 items and includes two subscales: state mindfulness of bodily sensations $(\alpha=0.90)$ and mental events $(\alpha=0.90)$. A Spanish adaptation performed by the authors was used and showed adequate internal consistency for the bodily sensations subscale (Cronbach's $\alpha=0.78-0.79$ ) and the mental events subscale (Cronbach's $\alpha=0.89-0.91$ ).

State self-compassion, positive affiliative affect, self-criticism, and feeling energized levels were assessed with the Visual analogue scales for state changes (VAS-SC; ranging from 0 to 100; [30]). Three questions were used to measure participants' affiliative affect states (Cronbach's $\alpha=0.77-0.76)$. Two questions asked about participants' self-compassion states (Cronbach's $\alpha=0.75-0.81$ ), one about their self-criticism states, and one about how energized they felt.

\subsubsection{Post-in-Person Session Measures}

Prosocial behavior was assessed using the Dictator's Game based on the procedure by Brocklebank et al. [31]. It is a multiple-decision tree format task in which participants have to allocate money between the person they are embodying and themselves. Participants have the choice to allocate the money in a compassionate or prosocial manner. Programming and administration of the task was accomplished with the Inquisit software [32].

Embodiment experience of VR participants was measured using an ad-hoc version of Longo et al.'s [6] questionnaire to assess the Rubber Hand Illusion experience. The scale is composed of 10 items rated on a 7-point Likert scale ranging from 1 (strongly disagree) to 7 (strongly agree). The scale contains 3 subscales: 5 items assess body-ownership (Cronbach's $\alpha=0.91$ ), 3 items assess location (Cronbach's $\alpha=0.61$ ), and the remaining 2 items assess agency (Cronbach's $\alpha=0.84$ ).

\subsubsection{Daily Follow-Up after the in-Person Session}

Frequency of meditation was obtained in the 2 weeks following the in-person session with daily questions (i.e., have you meditated today?).

Compassion-based meditation quality was assessed after every meditation at home using the Compassion Practice Quality Scale (CPQS, [14]). This includes 10 items that participants score on a scale ranging between 0 and 100, indicating the percentage of the time that their experience reflects each statement. The scale is composed of an imagery factor (Cronbach's $\alpha=0.80-0.93$ in this sample) and a somatic factor (Cronbach's $\alpha=0.70-0.90$ ). 


\subsection{Procedure}

Professionals from healthcare institutions or healthcare students were invited to participate in a study aimed at increasing their compassionate skills toward their patients. The study was advertised online (social networks such as Instagram) and via flyers and posters in the faculties of psychology, medicine, and nursing of the University of Valencia. Potential participants contacted researchers via email and received access to the informed consent. Then, the screening/baseline assessment was performed (sociodemographic adhoc questionnaire, PANAS, and CLS). Participants who met the inclusion and exclusion criteria were randomly assigned to one of the two study conditions: regular audio guided meditation (audio condition) or meditation supported by an embodied-VR system "The machine to be another (TMTBA; VR condition)", using Random Allocation Software 2.0. Participants were invited to an in-person laboratory session and filled out the preassessment materials (SMS and VAS-SC). Once they had finished, participants in the Audio condition were seated in a quiet room and listened to a recorded "inner dialogue" audio with the description of the situation and feelings of a patient suffering severe anxiety disorder (with panic attacks), followed by instructions to perform a traditional compassion meditation. Participants in the VR condition followed the steps explained in the section below. For both conditions, the same patient's narrative (Appendix A) and meditation audio (Appendix $B$ ) were used. The meditation focused on generating compassion for the presented case, inviting participants to connect with the suffering of another (panic patient) and activate the desire and willingness to alleviate this suffering. At the end, a compassionate mantra was used. Once participants finished the meditation, they completed the postassessment measures (SMS, VAS-SC, embodiment experience ad-hoc questionnaire, and the Dictator's Game). Over the following period of 14 days, participants were asked to meditate using an audio track with the meditation performed in the laboratory session and report their frequency of meditation and compassion-based meditation quality (CPQS) on a daily basis (minimum of one meditation a day, about 15-20 min per day). At the end of the two-week period, participants completed the follow-up assessment (PANAS and CLS).

\subsubsection{The VR Condition}

The VR condition used an embodied system so participants could experience the perceptual illusion of a body swap with a person with a panic disorder. The required hardware for this experiment is a vest with a camera, a head-mounted display (VR Oculus Rift), earphones, and a computer with the TMTBA software. The vest was connected to the head-mounted display, and the performer's first-person perspective was captured by the camera controlled by the participants' head movements, revealing the torso, legs, and arms of the performer's body, as well as the room. Through the Oculus, the user saw the image captured by the camera, creating the illusion of being another person. Two researchers were present in all sessions to run the experiment: the performer and an assistant. The performer was a person who was trained to synchronously mimic the user's movements to induce the embodied illusion. The assistant was responsible for setting up the hardware and the software.

Before participants arrived, the system was tested and calibrated. In the calibration process, the performer wore both the head-mounted display and the vest, and then he stretched both arms in front of the head. Finally, the assistant had to calibrate the camera and the Oculus through the software, so the image was centered and consistent with the performer's usual point of view. That is, the assistant ensured that the camera pointed in the same direction as the Oculus. Despite this procedure, a slight desynchronization was expected in the synchrony of interactions due to human factors, such as latency or eventual imprecisions of the performer. Hence, to control the user's movements, the audio recordings requested precise and slow movements. 
Once participants arrived and filled out the questionnaires, they were told that they were going to embody a person diagnosed with panic attack disorder, and the performer was going to help in that process with his body. Participants were asked to sit on a chair and wear the head-mounted display and earphones. The assistant helped them remove rings, bracelets, clocks, and to wear the gear, ensuring they felt comfortable. At this moment, the image was turned off (they saw a black screen), and participants listened to a greeting message that explained the three phases in which the experiment was divided (Figure 2). Meanwhile, the performer quickly changed his shirt to short or long sleeved, depending on the participants' clothes. The performer quietly wore the vest and was seated two meters to the right and one meter in front of the participant, in parallel, and looking in the same direction. This location was previously chosen to ensure that participants could not see themselves from the performer's position and the performer could see them by turning his neck without discomfort.

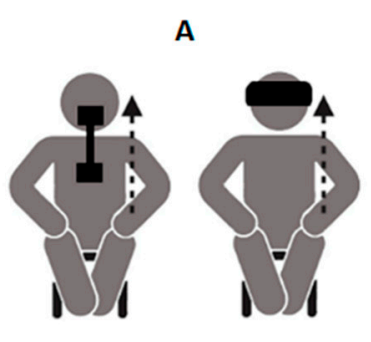

Embodied Illusion

Audio + Visual-Haptic Sync
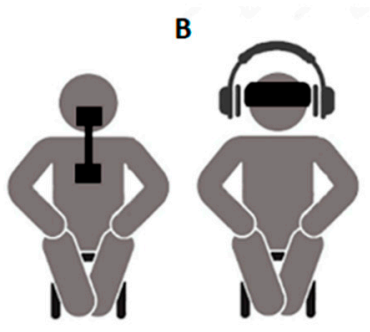

Emphatic induction

Audio + Visual-Haptic Sync

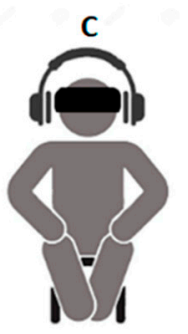

Compassion Meditation

Audio only

Figure 2. Phases of the virtual reality (VR) condition. (A) Body swap illusion phase: the participant takes over the body of the performer/person with panic disorder; (B) the participant listens to the story of the person with panic disorder; $(\mathbf{C})$ the participant performs a compassion-based meditation to enhance the desire to alleviate the embodied person's suffering.

The purpose of the first phase was to generate a body swap illusion, allowing the participant to take over the body of another person (the performer/person with panic disorder) (Figure 2A). To do so, an embodied induction was performed. In this phase, the image was turned on, thus revealing the performer's first-person perspective. A prerecorded instruction to perform specific movements was played to the participant (e.g., "Put your right hand on your right knee, and then slowly move it up to your lap, as if you were caressing it"). All the movements selected followed two principles: (1) movements that require a combination of visual and haptic senses, in order to increase the embodied illusion; (2) movements that ensure the synchronization between the participant's and performer's movements. This phase lasted $5 \mathrm{~min}$. Later (Figure 2B), the participant listened to an "inner dialogue" narrative of a patient with panic disorder who describes their dayto-day suffering experiences related to their symptomatology. At the same time, the performer continues to mirror the participant's free movements. This phase of emphatic induction lasted $4 \mathrm{~min}$ and $30 \mathrm{~s}$. At the end of the patient's narrative, the participant was still wearing the VR Oculus Rift, but it was turned off and the third phase began (Figure 2C). A compassion-based meditation was played to the participant for $3 \mathrm{~min}$. At the same time, the performer took off the vest and put it in place. The meditation aimed to enhance the desire to alleviate the patient's suffering after participants had embodied him during the experiment.

\subsubsection{The Audio Condition}

The audio condition was divided into two phases. First, the participant was instructed to wear sight-blocking glasses in order to reduce the potential distraction of ex- 
ternal stimuli and to generate a condition as similar as possible to the VR condition. Afterwards, the participant listened to the story of a patient with a panic disorder who described their day-to-day suffering experiences related to their symptomatology (empathic induction). At the end, a compassion-based meditation was played to the participant (Figure 3).
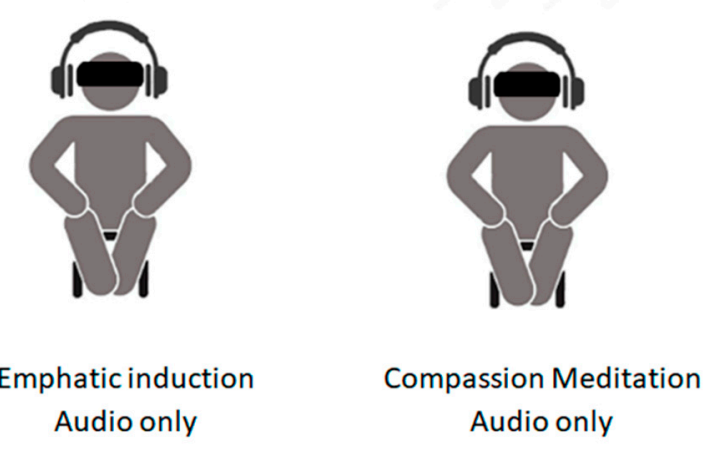

Figure 3. Phases of the audio condition.

\subsection{Data Analyses}

Data were statistically evaluated using IBM SPSS for Windows, version 26 . To check that no baseline differences existed between the two conditions, a Chi-Square Test was performed for sex, Mann-Whitney U Test for age, and independent-sample t-test for outcomes.

Regarding the efficacy of the in-person session practices, we examined the withinsubjects differences for the SMS and VAS-SC scores comparing pretest/post-test scores with paired-sample t-tests. Additionally, we performed a one-sample t-test for the VR condition to investigate the effect of TMTBA on the embodiment scores. A significantly greater score than 1 meant that participants experienced location, ownership, or agency of the performer's body. The score of 1 is equivalent to the nonexperience of location, ownership, or agency of the performer's body. Then, SMS and VAS-SC scores were analyzed using analysis of covariance (ANCOVA) with the between-subjects factor as condition, and baseline scores as covariates. Moreover, independent $t$-tests were performed on the amount of participants' money in the Dictator's Game.

Regarding the efficacy of the intervention, we conducted paired-sample t-tests to examine within-subjects' differences for PANAS and CLS scores. Moreover, PANAS and CLS scores were analyzed using ANCOVA with the between-subjects factor as condition, and the baseline scores as covariates. Finally, an ANCOVA was used to explore differences between groups in meditation practice frequency while statistically controlling for participants' ordinary weekly practice.

For the ANCOVAs, preliminary checks were conducted to ensure no violation of the assumptions of normality, linearity, homogeneity of variances, homogeneity of regression slopes, and reliable measurement of the covariate.

\section{Results}

The sociodemographic characteristics of all participants at baseline are shown in Table 1. All participants reported no use of drugs and an absence of mental or chronic illness. There were no significant differences between conditions according to sex (chisquare $(2, n=41)=0.01, p=0.940$, phi $=0.01$ or age $U=240, z=0.79, p=0.429)$ and age $(\mathrm{U}=$ $240, \mathrm{z}=0.79, p=0.429)$. Mean age of VR participants was $23.52(\mathrm{SD}=5.42)$, while audio participants were on average 22.15 years old $(S D=3.96)$. Moreover, there was no significant difference regarding habitual meditation practice frequency between VR participants $(M=0.86 ; S D=2.41)$ and audio participants $(M=0 ; S D=0 ; t(20)=-1.63, p=0.119$, two- 
tailed, eta squared $=0.06$ ). Finally, most of the sample was composed of students of psychology, except for five participants, of which were a doctor, a physiotherapist, a dentist, a nurse, and a pharmacist. The last three professionals were in the audio condition.

Table 1. Sociodemographic characteristics of participants at baseline.

\begin{tabular}{|c|c|c|c|c|c|c|}
\hline \multirow[t]{2}{*}{ Baseline Characteristic } & \multicolumn{2}{|c|}{ VR } & \multicolumn{2}{|c|}{ Audio } & \multicolumn{2}{|c|}{ Full Sample } \\
\hline & $n$ & $\%$ & $n$ & $\%$ & $n$ & $\%$ \\
\hline \multicolumn{7}{|l|}{ Gender } \\
\hline Female & 17 & 81 & 16 & 80 & 33 & 80.5 \\
\hline Male & 4 & 19 & 4 & 20 & 8 & 19.5 \\
\hline \multicolumn{7}{|l|}{ Highest educational level } \\
\hline Middle school & 2 & 9.5 & 4 & 20 & 6 & 14.6 \\
\hline High school/some college & 13 & 61.9 & 13 & 65 & 26 & 63.4 \\
\hline $\begin{array}{c}\text { University or postgraduate } \\
\text { degree }\end{array}$ & 6 & 28.6 & 3 & 15 & 9 & 22 \\
\hline \multicolumn{7}{|l|}{ Previous experience a } \\
\hline Meditation practice & 5 & 23.8 & 5 & 25 & 10 & 24.4 \\
\hline Compassion practice & 4 & 19.05 & 2 & 10 & 6 & 14.63 \\
\hline \multicolumn{7}{|l|}{$\begin{array}{c}\text { Meditation practice fre- } \\
\text { quency }\end{array}$} \\
\hline Never & 18 & 85.71 & 20 & 100 & 38 & 92.68 \\
\hline 1 time per week & 1 & 4.76 & 0 & 0 & 1 & 2.44 \\
\hline 4 times per week & 2 & 9.53 & 0 & 0 & 2 & 4.88 \\
\hline
\end{tabular}

Note. $\mathrm{N}=41$ ( $n=21$ for participants of VR condition and $n=20$ for participants of audio condition).

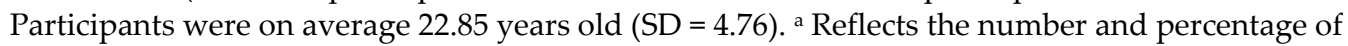
participants answering "yes" to this question.

\subsection{Efficacy of the in-Person Session Practices}

Descriptive statistics, independent-sample t-test for baseline scores, and ANCOVA results are shown in Tables 2 and 3. VR and audio participants had no significantly different baseline scores in SMS and VAS-SC.

Table 2. Descriptive statistics and independent-samples t-test results of baseline data.

\begin{tabular}{|c|c|c|c|c|c|c|c|}
\hline \multirow[b]{2}{*}{ Variables } & \multicolumn{2}{|c|}{$\operatorname{VR}(n=21)^{\mathrm{a}}$} & \multicolumn{2}{|c|}{ Audio $(n=20)^{\text {a }}$} & \multicolumn{3}{|c|}{ t-Student } \\
\hline & Pre & Post & Pre & Post & $t$ & $p$ & $\eta^{2}$ \\
\hline $\begin{array}{l}\text { SMS (Total } \\
\text { Score) }\end{array}$ & 74.65 (14.28) & 85.29 (11.73) & $67.30(13.34)$ & 82.68 (11.29) & $t(38)=-1.68$ & 0.101 & 0.07 \\
\hline $\begin{array}{l}\text { SMS (Body sub- } \\
\text { scale) }\end{array}$ & $20.86(4.70)$ & $22.43(4.14)$ & $18.05(4.65)$ & $21.30(5.30)$ & $t(39)=-1.92$ & 0.062 & 0.09 \\
\hline $\begin{array}{l}\text { SMS (Mind sub- } \\
\text { scale) }\end{array}$ & $53.80(10.22)$ & $62.86(9.10)$ & 49.25 (10.17) & $61.16(7.48)$ & $t(38)=-1.41$ & 0.166 & 0.05 \\
\hline $\begin{array}{l}\text { VAS-SC (Self- } \\
\text { compassion) }\end{array}$ & $11.93(4.36)$ & $11.71(4.58)$ & $11(3.52)$ & $11.48(3.86)$ & $t(39)=-0.80$ & 0.429 & 0.02 \\
\hline $\begin{array}{l}\text { VAS-SC (Posi- } \\
\text { tive affiliative } \\
\text { affect) }\end{array}$ & $23.44(3.14)$ & $23.33(3.74)$ & $21.85(5.72)$ & $20.90(5.21)$ & $t(39)=-1.00$ & 0.324 & 0.03 \\
\hline $\begin{array}{l}\text { VAS-SC (Self- } \\
\text { criticism) }\end{array}$ & $7.40(1.76)$ & 7.05 (1.95) & $7.53(1.73)$ & 7.08 (1.76) & $t(39)=0.18$ & 0.859 & 0 \\
\hline $\begin{array}{l}\text { VAS-SC (Ener- } \\
\text { gized level) }\end{array}$ & $6.70(1.77)$ & $6.10(1.37)$ & $7.00(2.18)$ & $5.83(1.66)$ & $t(39)=0.31$ & 0.761 & 0 \\
\hline $\begin{array}{l}\text { PANAS (Posi- } \\
\text { tive Affect) }\end{array}$ & $32.14(5.58)$ & $32.53(7.33)$ & $30.20(7.54)$ & $32.56(5.60)$ & $t(39)=-0.94$ & 0.353 & 0.02 \\
\hline
\end{tabular}


PANAS (Nega-

tive Affect) 16.52 (3.39) 17.79 (7.49) 16.75 (4.58) 17.06 (4.95) $t(39)=0.18$ 0.858 0 118.52 (16.54)

Note. PANAS = Positive and Negative Affect Scale; CLS = Compassion Love Scale; SMS = State Mindfulness Scale; VAS$\mathrm{SC}=$ Visual Analogic States for State Changes. ${ }^{a}$ All values represent the means (and standard deviations in parenthesis).

Table 3. Paired-samples t-tests and analyses of covariance (ANCOVAs) results for PANAS, CLS, SMS, and VAS-SC scores.

\begin{tabular}{|c|c|c|c|c|c|c|c|c|c|}
\hline \multirow{3}{*}{ Variables } & \multirow{2}{*}{\multicolumn{3}{|c|}{$\begin{array}{c}\text { VR }(n=21) \\
\text { t-Student }\end{array}$}} & \multirow{2}{*}{\multicolumn{3}{|c|}{$\begin{array}{c}\text { Audio }(n=20) \\
\text { t-Student }\end{array}$}} & \multirow{2}{*}{\multicolumn{3}{|c|}{ ANCOVA }} \\
\hline & & & & & & & & & \\
\hline & $t$ & $p$ & $\eta^{2}$ & $t$ & $p$ & $\eta^{2}$ & $F$ & $p$ & $\eta_{p^{2}}$ \\
\hline \multicolumn{10}{|l|}{$\begin{array}{l}\text { Pre- and post-in-person session assess- } \\
\text { ment }\end{array}$} \\
\hline SMS (Total Score) & $t(19)=-3.17$ & 0.005 & 0.35 & $t(18)=-3.94$ & 0.001 & 0.46 & $F(1,36)=0.01$ & 0.924 & 0.00 \\
\hline SMS (Body subscale) & $t(20)=1.76$ & 0.093 & 0.13 & $t(19)=1.93$ & 0.068 & 0.16 & $F(1,38)=0.15$ & 0.700 & 0.00 \\
\hline SMS (Mind subscale) & $t(19)=3.47$ & 0.003 & 0.39 & $t(18)=4.67$ & 0.000 & 0.55 & $F(1,36)=0.00$ & 0.952 & 0.00 \\
\hline VAS-SC (Self-compassion) & $t(20)=0.21$ & 0.838 & 0.00 & $t(19)=-1.02$ & 0.320 & 0.05 & $F(1,38)=0.35$ & 0.556 & 0.00 \\
\hline VAS-SC (Positive affiliative affect) & $t(20)=0.29$ & 0.775 & 0.00 & $t(19)=1.50$ & 0.150 & 0.11 & $F(1,37)=1.37$ & 0.248 & 0.04 \\
\hline VAS-SC (Self-criticism) & $t(19)=1.85$ & 0.079 & 0.15 & $t(19)=1.16$ & 0.261 & 0.07 & $F(1,37)=0.03$ & 0.868 & 0.00 \\
\hline VAS-SC (Energized level) & $t(20)=1.78$ & 0.090 & 0.14 & $t(19)=2.63$ & 0.017 & 0.27 & $F(1,37)=1.39$ & 0.245 & 0.04 \\
\hline \multicolumn{10}{|l|}{ Pre- and postintervention assessment } \\
\hline PANAS (Positive Affect) & $t(18)=-0.05$ & 0.962 & 0.00 & $t(15)=-0.86$ & 0.405 & 0.05 & $F(1,32)=0.23$ & 0.633 & 0.01 \\
\hline PANAS (Negative Affect) & $t(18)=-0.90$ & 0.378 & 0.04 & $t(15)=-0.95$ & 0.358 & 0.06 & $F(1,32)=0.00$ & 0.947 & 0.00 \\
\hline CLS & $t(18)=0.25$ & 0.809 & 0.00 & $t(14)=0.15$ & 0.883 & 0.00 & $F(1,31)=0.07$ & 0.797 & 0.00 \\
\hline
\end{tabular}

Note. PANAS = Positive and Negative Affect Scale; CLS = Compassion Love Scale; SMS = State Mindfulness Scale; VAS$\mathrm{SC}=$ Visual Analogic States for State Changes.

Regarding the body swap induction, scores in the embodiment experience questionnaire were significantly greater than 1 [(location $(M=5.29 ; S D=1.11 ; t(20)=17.66, p<$ $0.001)$, ownership $(M=4.69 ; S D=1.40 ; t(20)=12.11, p<0.001)$, and agency $(M=5.81 ; S D$ $=0.90 ; t(20)=24.46, p<0.001)]$. That is, the induction was effective in generating the body swap and creating a feeling of being located in, having agency over, and owning the performer's body.

In both conditions, there was a statistically significant increase in SMS scores from the previous moment to the in-person session and after it. Moreover, audio participants had significant low levels of energy after the session. However, after adjusting for pretest scores, differences in these outcomes between the two groups were not found.

Finally, independent-samples t-tests were conducted to compare the Dictator's Game scores for TMTBA and audio conditions. There was a significant difference in the Dictator's Game between money that VR participants decided to retain $(M=2134.52 ; S D=$ $122.60)$ and money they decided to give to the embodied patient $(M=3053.57 ; S D=390.38$; $t(20)=10.29, p>0.001$, two-tailed, eta squared $=0.84)$, with audio participants gaining an inferior quantity of money $(M=2121.25 ; S D=117.90)$ than the patient $(M=2932.50 .52 ; S D$ $=406.62 ; t(19)=8.57, p<0.001$, two-tailed, eta squared $=0.79)$. Nevertheless, there was no significant effect for condition on the amount that the patient received, $t(39)=-0.97, p=$ 0.337 , two tailed, eta squared $=0.02$ ), nor on the money that participants retained, $t(39)=$ $-0.35, p=0.726$, two tailed, eta squared $=0.00$ ), despite VR participants giving more money to the patient than audio participants.

\subsection{Efficacy of the Intervention}

Descriptive statistics, independent-sample t-test for baseline scores, and ANCOVA results are shown in Tables 2 and 3. VR and audio participants had no significantly different baseline scores in PANAS and CLS. After adjusting for PANAS and CLS pretest scores, there were no significant differences in these outcomes between the two groups. However, comparing average meditation practice during the previous two weeks to the aver- 
age frequency during the two weeks after the session (paired-samples t-test), VR participants' day-to-day practice increased significantly $(M=6.52 ; S D=4.08 ; t(20)=-6.79, p<$ 0.001 , two-tailed, eta squared $=0.70)$, as did audio participants' practice $(M=3.30 ; S D=3.13$; $t(19)=-4.71, p<0.001$, two-tailed, eta squared $=0.54)$. Moreover, after adjusting for previous meditation practice frequency (ANCOVA), the difference between the two groups in average meditation practice during the two weeks after the session was significant $-F(1$, $38)=5.49, p=0.024$, partial eta squared $=0.13$. Regarding the overall quality of at-home compassion-based meditations, there was no significant effect of condition on the imagery component of quality nor the somatic one after adjusting for frequency of at-home meditation. See Table 4 for means, standard deviations, and ANCOVAs of participants' scores in CPQS factors.

Table 4. Means and standard deviations of scores on compassion practice quality.

\begin{tabular}{|c|c|c|c|c|c|c|c|}
\hline \multirow{2}{*}{ Variable } & \multicolumn{2}{|c|}{ VR $(n=21)$} & \multicolumn{2}{|c|}{ Audio $(n=20)$} & \multicolumn{3}{|c|}{ ANCOVA $^{a}$} \\
\hline & $M$ & $S D$ & $M$ & $S D$ & $F$ & $p$ & $\eta_{p 2}$ \\
\hline $\begin{array}{l}\text { Imagery Factor } \\
\text { (CPQS) }^{b}\end{array}$ & 60.69 & 13.57 & 64.31 & 15.96 & $F(1,31)=0.69$ & 0.413 & 0.00 \\
\hline 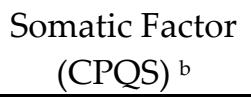 & 52.41 & 11.73 & 57.11 & 16.31 & $F(1,31)=2.04$ & 0.163 & 0.06 \\
\hline
\end{tabular}

Note. ES = Emotions Scale; CPQS = Compassion Practice Quality Scale. ${ }^{\text {a }}$ ANCOVAs were adjusted for frequency of at-home meditation. ${ }^{\mathrm{b}} \mathrm{CPQS}$ average scores for the two weeks of at-home meditations.

\section{Discussion}

The aim of the present paper was to evaluate the efficacy of a meditation supported by an embodied-VR experience to increase the quality and adherence to the practice of meditation, compassionate response to suffering of oneself and others, motivation to help others, and an altruistic response. Within this objective, two groups of healthcare professionals received a recorded "inner-dialogue" narrative of a person who suffers panic attacks, and a compassion meditation for that person. Furthermore, both groups were randomized into two conditions - the experimental one received an embodied-VR experience inviting them to "put themselves into the body of the person whose narrative was being heard" followed by the meditation, and the control, who just received the audio and the meditation. Afterwards, both groups were invited to practice the same meditation for two weeks.

The results confirm that both conditions (audio + embodied-VR and only audio) were effective in increasing state mindfulness, empathy, compassionate states, motivation to help, and altruism. However, interventions were not effective in reducing negative affect, and increasing positive affect, self-compassion, or dispositional compassion. The embodied-VR condition was not more effective than only the audio one in creating a compassionate experience or increasing practice quality. In this sense, data showed that the audio condition was very effective, showing that listening to the patient's "inner dialogue" narrative generated a very intense experience. In this sense, a potential explanation lies in the nature of the selected sample, given that healthcare professionals may already have high levels of empathy and compassion [33], having possibly reached a ceiling effect.

In accordance with our hypothesis, results suggest that an embodied-VR experience increases adherence to meditation practice for the following two weeks. In this line, Cappellen et al. [22] carried out a psychoeducational microintervention based on the upward spiral theory of lifestyle change to test if experiencing positive affect during first-time loving-kindness meditation experience predicts subsequent frequency and duration of meditation over the following 3 weeks. The results showed that the more positive affect during the meditation in the in-person session, the more frequent and longer the meditations were at home. However, the difference in average meditation practice during the three 
weeks after the session was not significant between the experimental and control groups. Thus, different factors could explain our result-it could be due to the potential activation of compassion and related positive emotions by complementing it with imagery skills [34] with the support of VR, which may lead to a greater adherence to meditation practice on a daily basis. Another explanation could be that the experience impacts the motivation to practice (but we have not evaluated this), and the motivation to alleviate others' suffering (although we have not seen differences in altruism measured by the Dictator's Game).

Therefore, these unclear results open the door to carry out new studies that expand these hypotheses. For instance, future studies should test this microintervention in participants from different professions and thus test the hypothesis of the compassion ceiling effect in healthcare professionals. Additionally, a better understanding of cognitive control processes associated with meditation practice [35] might be achieved with the use of TMTBA.

Limitations of the current study should be pointed out. The first is that well-established compassion questionnaires were not included in the study, such as the Sussex-Oxford compassion scale [36]. Moreover, imagery skills were not evaluated despite these variables being helpful to explain the effects of the intervention. In addition, most of the sample was composed of students of psychology, which hinders the generalizability of the findings. Finally, the size of the sample was calculated according to the effect of TMTBA on adherence reported in a previous study; thus, it might have been underpowered for the rest of variables. Related to this, we performed multiple statistical tests to compare groups failing to correct for multiple comparisons in order to avoid inflating type II error.

\section{Conclusions}

The results of this article could be interesting on several levels. On the one hand, we sought to refine the quality and frequency of compassion-based meditation practice at home and the use of TMTBA allowed us to discover that embodying the person to whom one generates compassion toward significantly increases the adherence to formal meditation practice at home. On the other hand, this technology can be used to generate a compassionate response for people who suffer from mental disorders, which suggests that it could be used in students pursuing a healthcare degree. More studies are needed to determine if there is a specific population with specific characteristics that may benefit from the use of VR for meditation training. However, the time, personnel, null results in terms of differences with traditional meditation practice in many measured dependent variables, and financial costs of TMTBA have to be taken into account when implementing this microintervention as a first contact for individuals who are going to undergo a compassion-based intervention.

Author Contributions: A.C., R.H., J.N., M.M.-S., M.B.-B., and R.B. designed the study (conceptualization and methodology). J.N. and M.M.-S. performed the recruitment and data curation. J.N. conducted the formal analyses and wrote the results section. A.C. and J.N. wrote the original draft. R.H., M.M.-S., M.B.-B, and R.B. collaborated in the writing and editing of the final manuscript. All authors have read and agreed to the published version of the manuscript.

Funding: This research received no external funding.

Institutional Review Board Statement: The study was conducted according to the guidelines of the Declaration of Helsinki, and approved by the Ethics Committee of Research in Humans of the Ethics Commission in Experimental Research of University of Valencia (H1513592028862; date: 11 January 2018).

Informed Consent Statement: Informed consent was obtained from all subjects involved in the study.

Data Availability Statement: The data presented in this study are available on request from the corresponding author. The data are not publicly available due to a privacy issue. 
Acknowledgments: This work was supported by CIBEROBN, an initiative of the ISCIII (ISC III CB06 03/0052), European Union's Horizon 2020 under Tactility (856718), and Ministerio de Economía y Competitividad (Spain) under AMABLE-VR (RTI2018-097835-A-I00).

Conflicts of Interest: The authors declare no conflict of interest.

\section{Appendix A}

Transcript of Patient's narrative

Mi vida básicamente se puede dividir en dos partes muy claras. La primera abarca hasta mis 25 años. Tuve una infancia normal, con bastantes amigos en el colegio. Recuerdo que lo pasaba muy mal cuando me tocaba salir a la pizarra, y como algunos niños del colegio se burlaban porque llevaba gafas. [My life can basically be divided into two very clear parts. The first part covers up to my 25th birthday. I had a normal childhood, with quite a few friends at school. I remember that I had a very bad time when it was my turn to go out to the blackboard, and how some children at school made fun of me because I was wearing glasses.]

Tuve la adolescencia normal, en la que casi siempre prefería ir de excursión con mis amigos antes que salir por las noches. Aunque sí que recuerdo pasarlo mal y ponerme super nervioso al hablar con chicas. [I had a normal teenage years, when I almost always preferred to go on excursions with my friends rather than go out in the evenings. Although I do remember having a hard time and getting super nervous talking to girls.]

Básicamente ha sido una vida normal, sin grandes sobresaltos, a los 25 estaba con un trabajo y una pareja estable, y con muchos planes de futuro. [Basically, it has been a normal life, without big shocks, at 25 I was with a job and a stable partner, and with many plans for the future.]

Hasta que llegó aquel fatídico día del mes de mayo de 2010. [Until that fateful day in May 2010.]

Ese día empezó la segunda parte de mi vida: de vacaciones, descansando de un año muy estresante y lleno de altibajos. Estaba viendo la televisión y sentado al lado de mi pareja, super a gusto, y no sé porque, o no recuerdo porque, mi corazón empezó a latir desbocado. Empecé a sentir como latía, parecía que se me salía del pecho, me dolía y no podía hacer nada para parar ese dolor. [That day began the second part of my life: on holiday, resting from a very stressful year full of ups and downs. I was watching TV and sitting next to my partner, super comfortable, and I don't know why, or I don't remember why, my heart started to beat wildly. I started to feel it beating, it seemed to be coming out of my chest, it hurt and I couldn't do anything to stop that pain.]

Me empecé a asustar, así que me marché al dormitorio sin decir nada y, me tumbé en la cama y me dije: "Tranquilo, relájate, que todo esto pasará". Pero mi corazón seguía por su cuenta. [I started to get scared, so I went to the bedroom without saying anything and, I lay down on the bed and I said to myself: "Calm down, relax, all this will pass". But my heart was still on its own.]

Mi pareja y una amiga me llevaron al centro de salud, donde me rodearon los médicos: en ningún otro lugar del mundo habría podido sentirme más seguro. Pero mi corazón seguía sin atender a razones. Finalmente, los médicos me dijeron que no era nada orgánico, que era psicológico. [My partner and a friend took me to the health centre, where I was surrounded by doctors: nowhere else in the world could I have felt safer. But my heart still didn't listen to reason. Finally, the doctors told me that it was nothing organic, that it was psychological.]

Aquel día sufrí el primer ataque de ansiedad de mi vida. $Y$, aunque logré reponerme, me pidieron que descansara durante una temporada. No lo hice. Pensé que se trataría de una cosa puntual, que no tendría mayor repercusión. Ahora arrastro ocho años de ataques continuos. Con mayor o menor intensidad, pero continuos. [That day I suffered the first panic attack of my life. And although I recovered, I was asked to rest for a while. I did not. I thought that it would be a one-off, that it wouldn't have a major impact. Now I have eight years of continuous panic attacks. With more or less intensity, but continuous.]

Resulta bastante complicado describir un ataque. En mi caso, quizás sea como un alud de nieve. Empiezo a notar los primeros síntomas y en un instante ya no hay refugio 
que valga. [It is quite complicated to describe a panic attack. In my case, perhaps it's like a snow avalanche. I begin to notice the first symptoms and, in an instant, there is no longer any shelter.]

En el momento en el que me ocurren los ataques, que pueden ser en cualquier momento, especialmente en los lugares con mucha gente, todo se suspende de repente. Trato de ser consciente de la realidad e intento cambiar el rumbo de mis pensamientos, pero entonces no existe nada más que ese presente angustioso. Por mucho que lo intente, ya no tengo el control de mi cuerpo. Siento que me ahogo, la taquicardia, el temor a morir, porque no sé lo que me te está pasando. [The moment the attack happens to me, which can be at any time, especially in crowded places, everything suddenly stops. I try to be aware of reality and I try to change the course of my thoughts, but then there is nothing but this distressing present. No matter how hard I try, I am no longer in control of my body. I feel like I'm drowning, I'm tachy, I'm afraid of dying, because I don't know what's happening to me.]

Durante todo este tiempo, no he dejado de preguntarme si volveré a ser el de antes. Mi mente ha luchado sin tregua para retornar a la primera parte de mi biografía. Pero no ha habido manera. [During all this time, I haven't stopped wondering if I'll ever be the same again. My mind has fought relentlessly to return to the first part of my biography. But there has been no way.]

Si una persona se cruzase conmigo, podría reconocerme porque siempre tengo las manos ocupadas, a veces llevo una pelota de estas blandas y la apreto incesantemente buscando una calma que nunca llega. Noto la presión de la pelota, y como por más que la apriete siempre vuelve a su forma original. Esto me permite sentirme como si alguien me llevara de la mano. Logró calmarme un poco con ella, pero llega un momento en que todas estas herramientas no sirven de nada: los ataques, en mi caso, siempre regresan y son implacables. [If a person crossed me, he would recognize me because my hands are always busy, sometimes I carry one of these soft balls and I squeeze it incessantly looking for a calm that never comes. I feel the pressure of the ball, and as much as I squeeze it, it always returns to its original shape. This allows me to feel as if someone is holding my hand. I manage to calm down a bit with it, but there comes a time when all these tools are useless: the attacks, in my case, always come back and are relentless.]

Como ésta, he desarrollado otras estrategias que me hacen sentir más tranquilo. Por ejemplo, siempre llevo una caja de ansiolíticos en el bolsillo. Todos los días antes de salir de casa compruebo que los llevo, es la única forma de saber que si me pasa algo por la calle tendré una salida. Si lo necesitase, podría coger o una pastilla, y ponerla debajo de la lengua para tranquilizarme. [Like this one, I have developed other strategies that make me feel more at ease. For example, I always carry a box of anxiolytics in my pocket. Every day before I leave home, I check that I have them with me, it's the only way to know that if something happens to me on the street, I will have a way out. If I need to, I could take a pill and put it under my tongue to calm down.]

Es difícil, en estas condiciones cuesta conocer gente. Cada vez que hablo con alguien, siento la amenaza de que me sobrevenga un nuevo ataque. Me he convertido en una persona huidiza, así que me he aferrado con fuerza a quienes ya conocía. [It is difficult, in these conditions it is hard to meet people. Every time I talk to someone, I feel the threat of another attack. I have become a person on the run, so I have held on tightly to those I already knew.]

Y más allá de nuestras relaciones personales, en la esfera social, el estigma es muy fuerte. A mí me duele cada vez que escucho la palabra "loco". Es una etiqueta estéril e hiriente que no sirve para nada. [And beyond our personal relationships, in the social sphere, the stigma is very strong. It hurts me every time I hear the word "crazy". It is a sterile and hurtful label that serves no purpose.]

Ahora tengo 32 años y ya han pasado 8 desde que empezaron los ataques. Mi vida dio un vuelco. Ni un solo día de mi vida he dejado de luchar por aceptar mi situación, por encontrar las herramientas que hagan más llevadera mi existencia. [I am now 32 years old and it has been 8 years since the attacks began. My life has been turned upside down. Not one day of my life has I stopped struggling to accept my situation, to find the tools to make my existence more bearable.] 
Pero tampoco ha pasado un solo día, en los últimos 8 años, en los que me haya preguntado si volveré a ser ese chico apacible, sociable y ligeramente nervioso que era. [But there hasn't been a day in the last 8 years when I've wondered if I'll ever be that gentle, sociable, slightly nervous boy again.]

\section{Appendix B}

Transcript of guided meditation track

Después de colocarse en su postura escogida para meditar, tómate un momento para detenerte en las ventajas de usar este tiempo para cultivar la compasión para ti y los demás. Con tanto sufrimiento en el mundo, ¿puedes imaginarte superando esa indiferencia y e imaginarte despertando una compasión ilimitada? ¿Imaginas esta compasión beneficiando al mundo? [After placing yourself in your chosen meditation posture, take a moment to dwell on the advantages of using this time to cultivate compassion for yourself and others. With so much suffering in the world, can you imagine overcoming that indifference and imagine awakening unlimited compassion? Can you imagine this compassion benefiting the world?]

Lleva tu conciencia a todo el campo de las sensaciones táctiles en el cuerpo. Como si te encontraras a un viejo amigo, dale a tu cuerpo toda tu atención sin ningún tipo de crítica. Simplemente busca estar presente, con tu cuerpo tal como es. [Take your consciousness into the whole realm of tactile sensations in the body. As if you were meeting an old friend, give your body your full attention without any criticism. Simply seek to be present, with your body as it is.]

Mientras descansas en el flujo de sensaciones en el cuerpo, puede notar áreas de tensión. Normalmente, podemos sentirnos tentados a rechazar o ignorar estas áreas de incomodidad y malestar. Pero hoy con un espíritu compasivo, tómate tiempo para posar tu atención en estas áreas y liberar la tensión con cada exhalación. [As you rest on the flow of sensations in the body, you may notice areas of tension. Normally, we may be tempted to reject or ignore these areas of discomfort and uneasiness. But today, in a spirit of compassion, take time to focus your attention on these areas and release the tension with each exhalation.]

A medida que continúas calmando tu cuerpo a través de la relajación, invítalo también a permanecer en quietud. Date un descanso del agotamiento de estar constantemente en movimiento. [As you continue to calm your body through relaxation, invite it to remain still as well. Give yourself a break from the exhaustion of being constantly on the move.]

Ahora, complementa las cualidades de relajación y quietud con el elemento de vigilancia. Si está sentado, deje que el esternón se levante ligeramente, de modo que al respirar su abdomen naturalmente pueda expandirse y liberarse. Si estás acostado, en posición supina sobre la espalda, recuerda usar esta postura como una plataforma para el cultivo meditativo de la compasión. [Now, complement the qualities of relaxation and stillness with the element of vigilance. If you're sitting, let your sternum rise slightly, so that as you breathe your abdomen can naturally expand and release. If you are lying down, in a supine position on your back, remember to use this posture as a platform for meditative cultivation of compassion.]

Lentamente, deja que tu respiración se establezca a su propio ritmo natural. Con cada exhalación liberar completamente cualquier esfuerzo por controlar la respiración y dejar que cada inhalación surja espontáneamente sin forzarla. [Slowly, let your breathing settle into its own natural rhythm. With each exhalation release completely any effort to control the breath and let each inhalation come in spontaneously without forcing it.]

Relaja la mente liberando todas las preocupaciones sobre el pasado y el futuro y deja que tu conciencia descanse en la simplicidad del momento presente. Deja descansar tu atención sobre las sensaciones de la respiración. [Relax the mind by releasing all concerns about the past and the future and let your consciousness rest in the simplicity of the present moment. Let your attention rest on the sensations of the breath.]

Comienza a conectar con la intención del cultivo meditativo de la compasión, donde deliberadamente despertamos la mente y traemos la valiente aspiración de aliviar el su- 
frimiento en nosotros mismos y en los demás. [Begin to connect with the intention of meditative cultivation of compassion, where we deliberately awaken the mind and bring the courageous aspiration to alleviate suffering in ourselves and others.]

Amablemente, dirige tu atención a la narrativa que acabas de escuchar. Trae sin temor a la mente el sufrimiento que esta persona está experimentando. Puedes pensar en su ansiedad, sus inseguridades, en todas las limitaciones que este sufrimiento le impone. Intenta conectar con esta experiencia, sin huir o suprimirla. Es probable que la experiencia te genere inquietudes e insatisfacción. En lugar de suprimir o evitar la experiencia, valientemente reconócela. Luego, permite que tu mente profundice en el sufrimiento y observa cómo naturalmente surge el deseo de aliviar este sufrimiento. Siente este impulso compasivo que todos llevamos dentro de nosotros mismos. [Kindly direct your attention to the patient's narrative that you have just listened. Fearlessly bring to mind the suffering that this person is experiencing. You can think of their anxiety, their insecurities, all the limitations that this suffering imposes on them. Try to connect with this experience, without running away or suppressing it. It is likely that the experience will cause you to be restless and dissatisfied. Instead of suppressing or avoiding the experience, courageously acknowledge it. Then allow your mind to go deeper into the suffering and observe how the desire to relieve this suffering naturally arises. Feel this compassionate impulse that we all carry within us.]

Comienza a despertar la virtud de la compasión. Con un espíritu de coraje inagotable, al respirar, genera el deseo sincero: "Que esté libre del sufrimiento y de sus causas". Mientras continúas extendiendo este deseo sincero con cada inhalación, imagina la carga de sufrimiento que se levanta lejos de su cuerpo y mente e imagina que experimenta gran satisfacción y alivio. Imagínate a esta persona libre del sufrimiento y de las causas que lo provocan. [With a spirit of inexhaustible courage breath and generate the sincere desire: "May he be free from suffering and its causes". As you continue to extend this sincere desire with each breath, imagine the burden of suffering that rises away from your body and mind and imagine that you experience great satisfaction and relief. Imagine this person free from suffering and the causes of suffering.]

Ahora trae a la mente a una persona que te importa profundamente y que sabes que está sufriendo. El sufrimiento de esta persona puede ser desencadenado por una enfermedad grave, angustia psicológica, conflictos interpersonales o problemas profesionales. Hay tantas maneras de que el sufrimiento puede ser provocado. Invoca la presencia de esta persona y la realidad de su sufrimiento en tu mente a través de una imagen mental o por lo que sientes por esta persona. [Now bring to mind a person that you care deeply about and that you know is suffering. This person's suffering can be triggered by serious illness, psychological distress, interpersonal conflicts or professional problems. There are so many ways that suffering can be triggered. Invoke the presence of this person and the reality of their suffering in your mind through a mental image or through what you feel for this person.]

Mientras sostienes a esta persona en tu mente, mira si puedes sentir que esta persona un ser vivo que se preocupa por estar libre de la experiencia del sufrimiento. [As you hold this person in your mind, see if you can feel that this person is a living being who cares about being free from the experience of suffering.]

Una vez que hayas establecido esta conexión con esta persona, con un espíritu de coraje inagotable, con cada inhalación despierta el anhelo sincero de compasión, "Que esté libre del sufrimiento y de sus causas". Continúa extendiendo este deseo compasivo con cada inhalación. [Once you have established this connection with this person, with a spirit of inexhaustible courage, with every breath awaken the sincere desire for compassion, "May he be free from suffering and its causes". Continue to extend this compassionate desire with each breath.]

Imagínate la carga del sufrimiento de esta persona siendo llevada lejos de su cuerpo y mente e imagínalo experimentando la satisfacción del alivio. Imagine a esta persona libre de sufrimiento y sus causas. [Imagine the burden of this person's suffering being carried away from his body and mind and imagine him experiencing the satisfaction of relief. Imagine this person free from suffering and its causes.] 
Una vez más, extiende tu conciencia a otro individuo, una comunidad o una región del mundo donde hay mucho sufrimiento y haz esta práctica como hemos hecho antes. [Once again, extend your awareness to another individual, a community or a region of the world where there is much suffering and do this practice as we have done before.]

$\mathrm{Y}$, por último, permite que tu corazón se expanda en todas las direcciones y toma conciencia del impulso natural que todos compartimos, una preocupación genuina por estar libres del sufrimiento. Con un espíritu de coraje inagotable, con cada inhalación extiende el deseo de compasión universal: "Que todos estemos libres del sufrimiento y de sus causas". [And finally, allow your heart to expand in all directions and become aware of the natural impulse that we all share, a genuine concern to be free from suffering. In a spirit of unending courage, with every breath extend the desire for universal compassion: "May we all be free from suffering and its causes".]

Imagínate el sufrimiento del mundo siendo izado y viviendo con alegría esa experiencia de alivio. [Imagine the suffering of the world being lifted up and living with joy that experience of relief.]

Libera todas las construcciones mentales y por un momento descansa en la luminosa pureza de la conciencia. Simplemente sé consciente de ser consciente. Lentamente, termina esta sesión. [Release all mental constructs and for a moment rest in the luminous purity of consciousness. Simply be aware of being aware. Slowly, end this session.]

\section{References}

1. Ventura, S.; Badenes-Ribera, L.; Herrero, R.; Cebolla, A.; Galiana, L.; Baños, R. Virtual reality as a medium to elicit empathy: A meta-analysis. Cyberpsychology Behav. Soc. Netw. 2020, 23, 667-676, doi:10.1089/cyber.2019.0681.

2. Ahn, S.J.; Le, A.M.T.; Bailenson, J.N. The effect of embodied experiences on self-other merging, attitude, and helping behavior. Media Psychol. 2013, 16, 7-38, doi:10.1080/15213269.2012.755877.

3. Groom, V.; Bailenson, J.N.; Nass, C. The influence of racial embodiment on racial bias in immersive virtual environments. Soc. Influ. 2009, 4, 231-248, doi:10.1080/15534510802643750.

4. Rosenberg, R.S.; Baughman, S.L.; Bailenson, J.N. Virtual Superheroes: using superpowers in virtual reality to encourage prosocial behavior. PLoS ONE 2013, 8, e55003, doi:10.1371/journal.pone.0055003.

5. Barbot, B.; Kaufman, J.C. What makes immersive virtual reality the ultimate empathy machine? Discerning the underlying mechanisms of change. Comput. Hum. Behav. 2020, 111, 106431, doi:10.1016/j.chb.2020.106431.

6. Longo, M.R.; Schüür, F.; Kammers, M.P.; Tsakiris, M.; Haggard, P. What is embodiment? A psychometric approach. Cognition 2008, 107, 978-998, doi:10.1016/j.cognition.2007.12.004.

7. Hopkins, J. Cultivating Compassion; Broadway Books: New York, NY, USA, 2001.

8. Kirby, J.N.; Tellegen, C.L.; Steindl, S.R. A meta-analysis of compassion-based interventions: Current state of knowledge and future directions. Behav. Ther. 2017, 48, 778-792, doi:10.1016/j.beth.2017.06.003.

9. López, A.; Sanderman, R.; Ranchor, A.V.; Schroevers, M.J. Compassion for others and self-compassion: Levels, correlates, and relationship with psychological well-being. Mindfulness 2018, 9, 325-331, doi:10.1007/s12671-017-0777-z.

10. Cosley, B.J.; McCoy, S.K.; Saslow, L.R.; Epel, E.S. Is compassion for others stress buffering? Consequences of compassion and social support for physiological reactivity to stress. J. Exp. Soc. Psychol. 2010, 46, 816-823, doi:10.1016/j.jesp.2010.04.008.

11. Brito-Pons, G.; Campos, D.; Cebolla, A. Implicit or explicit compassion? Effects of compassion cultivation training and comparison with mindfulness-based stress reduction. Mindfulness 2018, 9, 1494-1508, doi:10.1007/s12671-018-0898-z.

12. Dahl, C.J.; Lutz, A.; Davidson, R.J. Reconstructing and deconstructing the self: Cognitive mechanisms in meditation practice. Trends Cogn. Sci. 2015, 19, 515-523, doi:10.1016/j.tics.2015.07.001.

13. Rinpoche, R. T., \& Mullen, K. (2005). The Buddhist use of compassionate imagery in mind healing. Compassion: Conceptualisations, research and use in psychotherapy, 218-238..

14. Navarrete, J.; Campos, D.; Diego-Pedro, R.; González-Hernández, E.; Herrero, R.; Baños, R.M.; Cebolla, A. Compassion-based meditation quality practice and its impact on the positive attitudes toward others. Mindfulness, under review.

15. Cebolla, A.; Herrero, R.; Ventura, S.; Miragall, M.; Bellosta-Batalla, M.; Llorens, R.; Baños, R.M. Putting oneself in the body of others: A pilot study on the efficacy of an embodied virtual reality system to generate self-compassion. Front. Psychol. 2019, 10, 1521, doi:10.3389/fpsyg.2019.01521.

16. Falconer, C.J.; Slater, M.; Rovira, A.; King, J.A.; Gilbert, P.; Antley, A.; Brewin, C.R. Embodying compassion: A virtual reality paradigm for overcoming excessive self-criticism. PLoS ONE 2014, 9, e111933, doi:10.1371/journal.pone.0111933.

17. De Oliveira, E. C., Bertrand, P., Lesur, M. E. R., Palomo, P., Demarzo, M., Cebolla, A., ... \& Tori, R. (2016, June). Virtual body swap: a new feasible tool to be explored in health and education. In 2016 XVIII Symposium on Virtual and Augmented Reality (SVR) (pp. 81-89). IEEE, Gramado (Brasil), Roraima Avenue, 1000, 97105-900. 
18. Cohn, M.A.; Fredrickson, B.L. In search of durable positive psychology interventions: Predictors and consequences of long-term positive behavior change. J. Posit. Psychol. 2010, 5, 355-366.

19. Rhodes, R.E.; Dickau, L. Experimental evidence for the intention-behavior relationship in the physical activity domain: A metaanalysis. Health Psychol. 2012, 31, 724-727, doi:10.1037/a0027290.

20. Layous, K.; Nelson, S.K.; Kurtz, J.L.; Lyubomirsky, S. What triggers prosocial effort? A positive feedback loop between positive activities, kindness, and well-being. J. Posit. Psychol. 2016, 12, 385-398, doi:10.1080/17439760.2016.1198924.

21. Rhodes, R.E.; Kates, A. Can the affective response to exercise predict future motives and physical activity behavior? A systematic review of published evidence. Ann. Behav. Med. 2015, 49, 715-731, doi:10.1007/s12160-015-9704-5.

22. Van Cappellen, P.; Catalino, L.I.; Fredrickson, B.L. A new micro-intervention to increase the enjoyment and continued practice of meditation. Emotion 2020, 20, 1332-1343, doi:10.1037/emo0000684.

23. Fredrickson, B.L. Chapter One-Positive emotions broaden and build. Adv. Exp. Soc. Psychol. 2013, 47, 1-53, doi:10.1016/b9780-12-407236-7.00001-2.

24. Santorelli, S.F.; Kabat-Zinn, J.; Blacker, M.; Meleo-Meyer, F.; Koerbel, L. Mindfulness-Based Stress Reduction (MBSR) Authorized Curriculum Guide 2017; Center for Mindfulness in Medicine, Health Care, and Society, University of Massachusetts Medical School: Worcester, MA, USA, 2017. Available online: https://www.umassmed.edu/contentassets/abe554ad1ced45b98c57e455441d3f95/mbsr-curriculum-guide-2017.pdf (accessed on 27 November 2019).

25. Segal, Z.V.; Williams, J.M.G.; Teasdale, J.D. Mindfulness-Based Cognitive Therapy for Depression: A New Approach to Preventing Relapse, 2nd ed.; Guilford Publications: New York, NY, USA, 2013.

26. Watson, D.; Clark, L.A.; Tellegen, A. Development and validation of brief measures of positive and negative affect: The PANAS scales. J. Personal. Soc. Psychol. 1988, 54, 1063-1070.

27. Robles, R.; Páez, F. Estudio sobre la traducción al español y las propiedades psicométricas de las escalas de afecto positivo y negativo (PANAS). Salud Ment. 2003, 26, 69-75.

28. Sprecher, S.; Fehr, B. Compassionate love for close others and humanity. J. Soc. Pers. Relatsh. 2005, 22, 629-651, doi:10.1177/0265407505056439.

29. Tanay, G.; Bernstein, A. State Mindfulness Scale (SMS): Development and initial validation. Psychol. Assess. 2013, 25, 1286-1299, doi:10.1037/a0034044.

30. Kirschner, H.; Kuyken, W.; Wright, K.; Roberts, H.; Brejcha, C.; Karl, A. Soothing your heart and feeling connected: A new experimental paradigm to study the benefits of self-compassion. Clin. Psychol. Sci. 2019, 7, 545-565.

31. Brocklebank, S.; Lewis, G.J.; Bates, T.C. Personality accounts for stable preferences and expectations across a range of simple games. Pers. Individ. Differ. 2011, 51, 881-886, doi:10.1016/j.paid.2011.07.007.

32. Millisecond Software. Inquisit's Dictator Game (Computer software), 2020. Available online: https://www.millisecond.com/download/library/dictatorgame/ (accessed on 13 November 2019).

33. Hojat M. (2016) Empathy as Related to Personal Qualities, Career Choice, Acquisition of Knowledge, and Clinical Competence. In: Empathy in Health Professions Education and Patient Care. Springer, Cham. https://doi.org/10.1007/978-3-319-27625-0 9

34. Kosslyn, S.M. Image and Brain: The Resolution of the Imagery Debate; MIT Press: Cambridge, MA, USA, 1994.

35. Incagli, F.; Tarantino, V.; Crescentini, C.; Vallesi, A. The effects of 8-week mindfulness-based stress reduction program on cognitive control: An EEG study. Mindfulness 2019, 11, 756-770, doi:10.1007/s12671-019-01288-3.

36. Gu, J.; Baer, R.; Cavanagh, K.; Kuyken, W.; Strauss, C. Development and psychometric properties of the Sussex-Oxford compassion scales (SOCS). Assessment 2020, 27, 3-20. 